\title{
HUBUNGAN TINGKAT STRES DENGAN SIKLUS MENSTRUASI PADA WANITA PREMENOPOUSE DI WILAYAH KERJA UPTD PUSKESMAS KUSUMADADI KECAMATAN BEKRI KABUPATEN LAMPUNG TENGAH
}

\author{
Novi Ambarwati ${ }^{1}$ \\ ${ }^{1}$ UPTD Puskesmas Kusumadadi Lampung Tengah \\ Email : noviambarwati037@gmail.com

\begin{abstract}
THE CORRELATION BETWEEN STRESS LEVEL AND MENSTRUAL CYCLE ON PREMENOPAUSAL WOMEN REGISTERED AT KUSUMADADI HEALTH CENTER OF BEKRI SUBDISTRICT OF LAMPUNG TENGAH REGENCY
\end{abstract}

Introduction : The length of menstrual cycle is influenced by age, weight, physical activity, stress level, gene, and nutrition. The average premenopausal age is 45 to 55 years. The causes of menstrual abnormality may be caused by either biologic (organic or dysfunction) or psychological problems such as stressful condition.

Objective: The objective of this study was to identify the correlation between stress level and menstrual cycle on premenopausal women registered at Kusumadadi Health Center of Bekri Subdistrict of Lampung Tengah Regency in 2020.

Method: This is a quantitative study which design is analytical survey and cross sectional approach. The population of this study comprises the whole premenopausal women aged 45 to 55 years registered at Kusumadadi Health Center of Bekri Subdistrict of Lampung Tengah Regency amounting to 1,266 people. The proportional random sampling technique resulted 304 respondents. Results : The data from Kusumadadi Health Center of Bekri Subdistrict of Lampung Tengah Regency revealed that there were 157 respondents (51.6\%) suffering stress and 158 respondents (52.0\%) having abnormal menstrual cycle. Conclusions: Based on the statistical analysis, the $p$ value was 0.000 implying that the $p$ value was < a value. It can be meant that there was a correlation between stress level and menstrual cycle on premenopausal women. This study can be used as a reference for the healt center to conduct a health seminar or training concerning stress level and menstrual cycle on premenopausal women.

Keywords : Stress Level, Menstrual Cycle 
INTISARI : HUBUNGAN TINGKAT STRES DENGAN SIKLUS MENSTRUASI PADA WANITA PREMENOPOUSE DI WILAYAH KERJA UPTD PUSKESMAS KUSUMADADI KECAMATAN BEKRI KABUPATEN LAMPUNG TENGAH

Pendahuluan : Panjangnya siklus menstruasi ini dipengaruhi oleh usia, berat badan, aktivitas fisik, tingkat stres, genetik dan gizi dan rata-rata dikatakan usia premenopause berkisar antara 45-55 tahun Penyebab gangguan menstruasi dapat karena kelainan biologik (organik atau disfungsional) atau dapat pula karena psikologik seperti keadaaan-keadaan stress.

Tujuan: Tujuan dari penelitian ini adalah diketahui Hubungan Tingkat Stres Dengan Siklus Menstruasi Pada Wanita Premenopouse Di Wilayah Kerja UPTD Puskesmas Kusumadadi Kecamatan Bekri Kabupaten Lampung Tengah Tahun.

Metode : Jenis penelitian adalah kuantitatif dengan rancangan dalam penelitian ini menggunakan survei analitik dengan menggunakan pendekatan cross sectional. Populasi dalam penelitian ini adalah seluruh wanita premenopouse yang berusia 45-55 tahun yang ada di Wilayah Kerja UPTD Puskesmas Kusumadadi Kecamatan Bekri Kabupaten Lampung Tengah yang berjumlah 1.266 orang, sehingga sampel dalam penelitian ini berjumlah 304 responden. Dalam penelitian ini teknik sampling yang digunakan adalah Proportional random sampling

Hasil : Diketahui bahwa Di Wilayah Kerja UPTD Puskesmas Kusumadadi Kecamatan Bekri Kabupaten Lampung Tengah, sebagian besar responden mengalami stress yang berjumlah 157 responden $(51,6 \%)$ dan sebagian besar responden mengalami siklus menstruasi yang tidak normal berjumlah 158 responden $(52,0 \%)$

Kesimpulan : Berdasarkan hasil uji statistik, didapatkan p-value 0,000 atau pvalue < nilai a $(0,05)$ yang artinya terdapat hubungan tingkat stres dengan siklus menstruasi pada wanita premenopouse. Hasil penelitian ini diharapkan agar dapat digunakan sebagai masukan untuk Puskesmas agar dapat mengadakan seminar atau pelatihan kesehatan tentang hubungan tingkat stres dengan siklus menstruasi pada wanita premenopouse.

Kata Kunci : : Tingkat Stres, Siklus Menstruasi

\section{PENDAHULUAN}

Banyak gejala-gejala yang sering dikeluhkan perempuan pada tahun-tahun berhentinya haid. Ini muncul akibat menurunnya hormone estrogen seperti, nyeri sendi dan sakit pada punggung, pengeringan pada vagina (sehingga sakit saat melakukan hubungan seksual), sulit menahan kencing, gangguan mood, dan emosi tinggi sehingga menimbulkan stress. Setelah itu penurunan kadar estrogen juga mengakibatkan kecenderungan peningkatan tekanan darah, pertambahanberat badan dan peningkatan kolesterol. Pada jangka panjang keluhan akibat menurunnya kadar estrogen ini dapat menyebabkan osteoporosis, penyakit jantung koroner, dementia tipe Alzheimer, stroke, kanker usus besar, gigi rontok dan katarak. Upaya yang perlu dan harus dilakukan anatara lain adalah mendapatkan informasi yang cukup tentang menopause serta mempertahankan kondisi kesehatan secara umum, seperti menghadapi kondisi menstruasi masa premenopouse (Kusumawardhani, 2016).

Siklus menstruasi merupakan waktu sejak hari pertama menstruasi sampai datangnya menstruasi periode berikutnya. Sedangkan 
panjang siklus menstruasi adalah jarak antara tanggal mulainya menstruasi yang lalu dan mulainya menstruasi berikutnya. Siklus menstruasi pada wanita normalnya berkisar antara 21-35 hari dan hanya $10-15 \%$ yang memiliki siklus menstruasi 28 hari dengan lama menstruasi 3-5 hari, ada yang 7-8 hari. Setiap hari ganti pembalut 2-5 kali. Lebih dari 90\% wanita premenopause akan mengalami perubahan dalam siklus haid. Siklus yang memendek antara 2-7 hari sangatlah khas. Siklus haid yang sebelumnya menetap tiap 28 hari akan menjadi siklus 25 atau 26 hari dan pada waktu terjadi premenopause kejadian oligomenore meningkat. Panjangnya siklus menstruasi ini dipengaruhi oleh usia, berat badan, aktivitas fisik, tingkat stres, genetik dan gizi (Wiknjosastro, 2015).

Berhentinya siklus menstruasi untuk selamanya bagi wanita yang sebelumnya mengalami menstruasi sebagi akibat dari hilangnya aktivitas folikel ovarium. Menopause diartikan sebagai tidak dijumpainya menstruasi selama 12 bulan berturut-turut dimana ovarium secara progresif telah gagal dalam memproduksi estrogen. Rata-rata dikatakan usia premenopause berkisar antara 45-55 tahun. Jumlah folikel yang mengalami atresia terus meningkat, hingga pada suatu ketika tidak tersedia lagi folikel yang cukup (WHO, 2016).

Tercatat dalam sebuah penelitian yang menyebutkan hampir seluruh perempuan di dunia mengalami sindrom pre-menopause, data menyebutkan bahwa di negaranegara Eropa mencapai 70-80\%, Amerika 60\%, Malaysia 57\%, China $18 \%$, serta Jepang dan Indonesia 10\% (Proverawati, 2010). Catatan tersebut mengemukakan bahwa banyak dari perempuan pada masa menjelang menopause mengalami perubahan, baik perubahan tersebut dalam hal fisik maupun psikologis (Fitriana, 2016).

$$
\text { Penyebab }
$$

menstruasi dapat karena kelainan biologik (organik atau disfungsional) atau dapat pula karena psikologik seperti keadaaan-keadaan stress dan gangguan emosi atau gabungan biologik dan psikologik. Faktorfaktor yang berperan yaitu (1) faktor psikologis, seperti tekanan hidup, stres, kecemasan, kelelahan fisik maupun psikis. (2) Gangguan yang bersifat hormonal yaitu ketidakseimbangan hormon estrogen maupun hormon progesteron dan prostaglandin. (3) Hormon prolaktin berlebih, meningkatnya hormon prolaktin secara otomatis akan menurunkan hormon estrogen dan progesteron. (4) Kenaikan atau berkurangnya berat badan secara signifikan. (5) Status gizi (underweight jika IMT 27,0) akan mempengaruhi kerja berupa peningkatan, keseimbangan, ataupun penurunan hormon. (6) Kelainan organik seperti radang, tumor, trauma dan sebagainya (Sarwono, 2012). Menurut penelitian sebelumnya oleh Mulastin (2016) ada hubungan antara stres dengan siklus menstruasi dan hasilnya bahwa menurut responden dengan umur 21 25 tahun sebanyak 25 orang $(40,3 \%)$, umur 26 - 30 tahun sebanyak 29 $(46,8 \%)$ dan umur 31-35 tahun sebanyak $8 \quad(12,9)$. Dengan hasil penelitian sebagian besar responden mengalami stres dengan siklus tidak normal sebanyak 26 orang $(41,9 \%)$. Dari hasil penelitian sebelumnya ada hubungan antara tingkat stress dengan siklus menstruasi.

Berdasarkan data dari Dinas Kesehatan Kabupaten Lampung Tengah tahunh 2019 berdasarkan jumlah penduduk, diketahui bahwa jumlah wanita usia 45-55 tahun yang paling tinggi ada $\mathrm{Di}$ Kecamatan 
Terbanggi Besar (Puskesmas Bandar Jaya dengan jumlah penduduk 11.774, dimana jumlah laki-laki mencapai 5.977 dan perempuan berjumlah 5.797 dan Puskesmas Poncowati dengan jumlah penduduk 10.636, dimana jumlah laki-laki mencapai 5.340 dan perempuan berjumlah 5.296), sedangkan jumlah penduduk terendah ada Di wilayah Kecamatan Kota Gajah (Puskesmas Kota Gajah jumlah penduduk mencapai 4.282, dimana jumlah lakilaki mencapai 2.169 dan jumlah perempuan mencapai 2.112 dan Puskesmas Sritejo Kencono dengan jumlah penduduk 1.878 dengan jumlah laki-laki mencapai 965 dan jumlah perempuan mencapai 913) (Profil Dinkes Kabupaten Lampung Tengah, 2019).

Berdasarkan hasil pra survey yang dilakukan peneliti pada tanggal 20 Januari 2020, jumlah wanita premenopouse tahun 2018 mencapai 4.505 orang dan pada tahun 2019 berjumlah 4.293 orang, berdasarkan hasil wawancara pada 10 wanita usia 40-50 tahun di wilayah kerja Puskesmas Kusumadadi Kecamatan Bekri Kabupaten Lampung Tengah didapatkan 5 wanita mengalami siklus normal (21-35 hari), sedangkan 3 wanita mengalami siklus terpanjang (>35 hari) dan 2 wanita mengalami siklus pendek yaitu (< 21 hari ) dan hasil wawancara didapatkan responden banyak yang mengalami gejala seperti susah tidur, gelisah dan mudah tersinggung hal ini menunjukan sebagian dari wanita yang menghadapi usia menopause mengalami stress yang berpengaruh pada siklus menstruasi.

Berdasarkan uraian tersebut di atas, maka peneliti tertarik melakukan penelitian dengan judul: "Hubungan Tingkat Stres Dengan Siklus Menstruasi Pada Wanita Premenopouse Di Wilayah Kerja UPTD Puskesmas Kusumadadi
Kecamatan Bekri Kabupaten Lampung Tengah Tahun 2020”.

\section{METODELOGI PENELITIAN}

Rancangan dalam penelitian ini menggunakan survei analitik dengan menggunakan pendekatan cross sectional yaitu peneliti mengambil data dalam satu waktu pada saat itu juga. Populasi dalam penelitian ini adalah seluruh jumlah wanita premenopouse yang berusia 45-55 tahun yang ada di Wilayah Kerja UPTD Puskesmas Kusumadadi Kecamatan Bekri Kabupaten Lampung Tengah yang berjumlah 1.266 orang. sampel dalam penelitian ini berjumlah 304 responden. Dalam penelitian ini teknik sampling yang digunakan adalah Proportional random sampling.

Tempat penelitian dilakukan Di Wilayah Kerja UPTD Puskesmas Kusumadadi Kecamatan Bekri Kabupaten Lampung Tengah. Dengan keterangan kelaikan etik dengan no. 989/EC/KEP-UNMAL/VII/ 2020. Instrumen penelitian adalah alat yang digunakan untuk mengumpulkan data dalam penelitian ini lembar kuesioner, dengan variabel stress pada responden, peneliti menggunakan lembar kuesioner, yang terdiri dari 10 pernyataan dengan option jawaban selalu (4), sering (3), cukup sering (2), kadang-kadang (1) dan tidak pernah (0). Alat pengumpul data dalam penelitian ini adalah lembar observasi HPHT untuk mengetahui apakah siklus menstruasi responden normal atau tidak melalui pertanyaan yang telah disediakan, jika dalam 3 bulan terakhir, 2 bulan siklus yang normal maka di katakana siklus normal, begitu juga dengan 
sebaliknya, jika dalam 3 bulan terakhir rata-rata siklus menstruasi tidak normal, maka dikategorikan siklus menstrusi tidak normal

Dalam penelitian ini menggunakan analisa univariat dan bivariat, analisis univariat menggunakan rumus presentase, Dalam penelitian ini peneliti menggunakan uji chi-square, jika terdapat nilai $p$-value $<0,05$, maka Ha diterima, begitu juga dengan sebaliknya jika $p$-value > 0,05, maka Ho diterima

\section{HASIL PENELITIAN}

Karateristik Responden

Tabel 1. Distribusi Frekuensi Usia, pendidikan, pekerjaan Responden Di Wilayah Kerja UPTD Puskesmas Kusumadadi Kecamatan Bekri Kabupaten Lampung Tengah

\begin{tabular}{ccc}
\hline $\begin{array}{l}\text { Usia } \\
\text { Responden }\end{array}$ & Frekuensi & $\begin{array}{c}\text { Persentase } \\
(\%)\end{array}$ \\
\hline 46 Tahun & 22 & 7.2 \\
47 Tahun & 16 & 5.3 \\
48 Tahun & 38 & 12.5 \\
49 Tahun & 37 & 12.2 \\
50 Tahun & 16 & 5.3 \\
51 Tahun & 37 & 12.2 \\
52 Tahun & 53 & 17.4 \\
53 Tahun & 16 & 5.3 \\
54 Tahun & 21 & 6.9 \\
55 Tahun & 48 & 15.8 \\
\hline Pendidikan & & \\
\hline D3 & 37 & 12.2 \\
SMA & 85 & 28.0 \\
SMP & 91 & 29.9 \\
SD & 91 & 29.9 \\
\hline Pekerjaan & & \\
\hline Buruh & 144 & 47.4 \\
Swasta & 16 & 5.3 \\
Wiraswasta & 144 & 47.4 \\
Buruh & 144 & 47.4 \\
\hline Jumlah & 304 & 100.0 \\
\hline
\end{tabular}

Berdasarkan tabel 1 diketahui bahwa Di Wilayah Kerja UPTD Puskesmas Kusumadadi Kecamatan Bekri Kabupaten Lampung Tengah, sebagian besar responden berusia 52 tahun yang berjumlah 53 responden $(17,4 \%)$. sebagian besar responden mempunyai pendidikan SD dan SMP yang berjumlah 91 responden

$(29,9 \%)$. sebagian besar responden mempunyai pekerjaan sebagai buruh dan wiraswasta yang berjumlah 144 responden $(47,4 \%)$. 
Analisis Univariat

Tabel 2 Distribusi Frekuensi Tingkat Stres Pada Premenopouse Di Wilayah Kerja UPTD Puskesmas Kusumadadi Kecamatan Bekri Kabupaten Lampung Tengah

\begin{tabular}{ccc}
\hline $\begin{array}{c}\text { Tingkat } \\
\text { Stres }\end{array}$ & Frekuensi & $\begin{array}{c}\text { Persentase } \\
\mathbf{( \% )}\end{array}$ \\
Tidak Stres & 147 & 48.4 \\
Stres & 157 & 51.6 \\
\hline Jumlah & 304 & 100.0 \\
\hline
\end{tabular}

Berdasarkan tabel 2 diketahui bahwa Di Wilayah Kerja UPTD Puskesmas Kusumadadi Kecamatan Bekri Kabupaten Lampung Tengah, sebagian besar responden mengalami stress yang berjumlah 157 responden $(51,6 \%)$.

Tabel 3 Distribusi Frekuensi Siklus Menstruasi Pada Premenopouse Di Wilayah Kerja UPTD Puskesmas Kusumadadi Kecamatan Bekri Kabupaten Lampung Tengah

\begin{tabular}{ccc}
\hline $\begin{array}{c}\text { Siklus } \\
\text { Menstruasi } \\
\text { Premenopouse }\end{array}$ & Frekuensi & $\begin{array}{c}\text { Persentase } \\
\text { (\%) }\end{array}$ \\
\hline Normal & 146 & 48.0 \\
Tidak Normal & 158 & 52.0 \\
\hline Jumlah & 304 & 100.0 \\
\hline
\end{tabular}

Berdasarkan tabel 3 diketahui bahwa Di Wilayah Kerja UPTD Puskesmas Kusumadadi Kecamatan Bekri Kabupaten Lampung Tengah,

\section{Analisa Bivariat}

Untuk mengetahui hubungan tingkat stres dengan siklus menstruasi pada wanita premenopouse $\mathrm{Di}$ Wilayah sebagian besar responden mengalami siklus menstruasi yang tidak normal berjumlah 158 responden $(52,0 \%)$.

Kerja UPTD Puskesmas Kusumadadi Kecamatan Bekri Kabupaten Lampung Tengah Tahun 2020, menggunakan uji Chi-Square Test :

Tabel 4. Analisis Hubungan Tingkat Stres Dengan Siklus Menstruasi Pada Wanita Premenopouse Di Wilayah Kerja UPTD Puskesmas Kusumadadi Kecamatan Bekri Kabupaten Lampung Tengah

\begin{tabular}{|c|c|c|c|c|c|c|c|c|}
\hline \multirow{3}{*}{$\begin{array}{c}\text { Tingkat } \\
\text { Stres }\end{array}$} & \multicolumn{4}{|c|}{ Siklus Menstruasi } & \multirow{2}{*}{\multicolumn{2}{|c|}{ Total }} & \multirow{3}{*}{$\begin{array}{c}\text { P- } \\
\text { Value }\end{array}$} & \multirow{3}{*}{$\begin{array}{c}\text { OR 95\% } \\
\mathrm{Cl}\end{array}$} \\
\hline & \multicolumn{2}{|c|}{ Normal } & \multicolumn{2}{|c|}{ Tidak Normal } & & & & \\
\hline & $\mathbf{N}$ & $\%$ & $\mathbf{N}$ & $\%$ & $\mathbf{N}$ & $\%$ & & \\
\hline Tidak Stres & 98 & 66,7 & 49 & 33,3 & 147 & 100,0 & 0,000 & 4,542 \\
\hline Stres & 48 & 30,6 & 109 & 69,4 & 157 & 100,0 & & $(2,803$ \\
\hline Jumlah & 146 & 48,0 & 158 & 52,0 & 304 & 100,0 & & $\begin{array}{c}- \\
7,359)\end{array}$ \\
\hline
\end{tabular}


Berdasarkan tabel 4, diketahui bahwa Di Wilayah Kerja UPTD Puskesmas Kusumadadi Kecamatan Bekri Kabupaten Lampung Tengah Tahun 2020, ada 147 responden yang tidak mengalami stress, dimana 98 responden $(66,7 \%)$ mengalami siklus menstruasi yang normal, dan 49 responden $(33,3 \%)$ mengalami siklus menstruasi tidak normal, sedangkan ada 157 responden yang mengalami stress, dmana 48 responden $(30,6 \%)$ mengalami siklus menstruasi normal dan 109 responden $(69,4 \%)$

\section{PEMBAHASAN}

\section{Tingkat Stres}

Berdasarkan tabel 2 diketahui bahwa Di Wilayah Kerja UPTD Puskesmas Kusumadadi Kecamatan Bekri Kabupaten Lampung Tengah, sebagian besar responden mengalami stress yang berjumlah 157 responden $(51,6 \%)$.

Stres menurut Hans Selye (2016) dalam buku Hawari (2008) adalah respon tubuh yang sifatnya non spesifik terhadap tuntutan beban atasnya. Dalam perkembangan selanjutnya ternyata dampak stres ini tidak hanya mengenai gangguan fungsional hingga kelainan organ tubuh, tetapi juga berdampak pada bidang kejiwaan (psikologik/ psikiatrik) misalnya kecemasan atau depresi. Gangguan pada sistem endokrin (hormonal) pada mereka yang mengalami stres adalah kadar gula yang meninggi, dan bila hal ini berkepanjangan bisa mengakibatkan yang bersangkutan menderita penyakit kencing manis (diabetes millitus), gangguan hormonal lain misalnya pada wanita adalah gangguan menstruasi yang tidak teratur.

ketika menopause tidak dapat mengalami siklus menstruasi tidak normal.

Berdasarkan hasil uji statistik, didapatkan $p$-value 0,000 atau $p$-value < nilai a $(0,05)$ yang artinya terdapat hubungan tingkat stres dengan siklus menstruasi pada wanita premenopouse $\mathrm{Di}$ Wilayah Kerja UPTD Puskesmas Kusumadadi Kecamatan Bekri Kabupaten Lampung Tengah Tahun 2020 dengan nilai OR 4,542 yang artinya responden yang mengalami stress akan berpeluang 4,542 kali lebih besar untuk mengalami siklus menstruasi yang tidak normal.

dipisahkan antara aspek organbiologis, sosial, budaya dan spiritual dalam kehidupan wanita. Beberapa gejala psikologis yang menonjol ketika menopause adalah mudah tersinggung, tertekan, gugup, kesepian, tidak sabar, tegang (tension), cemas, stres, dan depresi. Stres adalah ketegangan fisik dan mental atau emosional karena tubuh kita merespon terhadap tuntutan, tekanan dan gangguan yang ada di sekeliling kita. Stres adalah suatu keadaan atau tantangan yang kapasitasnya diluar kemampuan seseorang oleh karena itu, stres sangat individual sifatnya (Prawiroharjho, 2016).

Hasil penelitian dan teori diatas sejalan dengan penelitian sebelumnya oleh Mulastin (2016) ada hubungan antara stres dengan siklus menstruasi dan hasilnya bahwa menurut responden dengan umur 21 25 tahun sebanyak 25 orang $(40,3 \%)$, umur 26 - 30 tahun sebanyak 29 (46,8\%) dan umur 31-35 tahun sebanyak $8 \quad(12,9)$. Dengan hasil penelitian sebagian besar responden mengalami stres dengan siklus tidak normal sebanyak 26 orang $(41,9 \%)$. Dari hasil penelitian sebelumnya ada hubungan antara tingkat stress dengan siklus menstruasi. 
Berdasarkan hasil penelitian diatas, maka menurut peneliti sebagian besar responden mengalami stress, hal ini dikarenakan berdasarkan fenomena di tempat pnelitian diketahui banyak faktor yang mempengaruhi kejadian stress, seperti keadaan emosional yang tidak stabil, terlalu banyak pikiran, dan persepsi yang salah dan kurang baik tentang menurunnya aktifitas fisik responden yang ditunjukkan dengan pribadi pencemas, pemarah, pencuriga, dan pemurung. Sedangkan faktor eksternal dapat berlangsung berbulan-bulan bahkan tahunan. Pencetus dari hal ini dapat berupa perceraian, kematian anggota keluarga, tempat kerja yang tidak nyaman, penyakit kronis, kemiskinan, bencana alam, dan jam kerja yang berlebihan.

\section{Siklus Menstruasi}

Berdasarkan tabel 3 diketahui bahwa Di Wilayah Kerja UPTD Puskesmas Kusumadadi Kecamatan Bekri Kabupaten Lampung Tengah, sebagian besar responden mengalami siklus menstruasi yang tidak normal berjumlah 158 responden (52,0\%).

$\mathrm{Di}$ ovarium, di bawah pengaruh FSH, beberapa folikel primordial berkembang menjadi folikel primer dan seterusnya folikel sekunder. Di uterus pula, terjadi aliran cairan menstruasi dari rahim menuju ke leher rahim, untuk kemudian keluar melalui vagina yang mengandung kira-kira 50-150 mL darah, cairan jaringan, mukus dan sel epitel yang luruh dari endometrium. Luruhnya dinding endometrium ini karena terjadi penurunan kadar hormon estrogen dan progesteron di mana akan menstimulasi pelepasan prostaglandin yang menyebabkan konstriksi arteriol spiral. Di ovarium, beberapa folikel sekunder akan mensekresi estrogen dan inhibin. Biasanya, hanya satu folikel sekunder yang akan berkembang menjadi folikel dominan dan yang lainnya mengalami atresia. Folikelfolikel sekunder yang mengalami atresia terjadi karena penurunan kadar FSH yang disebabkan oleh estrogen dan inhibin yang disekresi oleh folikel dominan. Seterusnya, folikel dominen akan berkembang menjadi folikel Graaf (graafian follicle) yang akan terus berkembang sehingga diameternya mencapai lebih kurang $20 \mathrm{~mm}$ dan tersedia untuk ovulasi (Proverawati, 2010).

Siklus menstruasi merupakan waktu sejak hari pertama menstruasi sampai datangnya menstruasi periode berikutnya. Sedangkan panjang siklus menstruasi adalah jarak antara tanggal mulainya menstruasi yang lalu dan mulainya menstruasi berikutnya. Siklus menstruasi pada wanita normalnya berkisar antara 21-35 hari dan hanya $10-15 \%$ yang memiliki siklus menstruasi 28 hari dengan lama menstruasi 3-5 hari, ada yang 7-8 hari. Setiap hari ganti pembalut 2-5 kali. Lebih dari 90\% wanita premenopause akan mengalami perubahan dalam siklus haid. Siklus yang memendek antara 2-7 hari sangatlah khas. Siklus haid yang sebelumnya menetap tiap 28 hari akan menjadi siklus 25 atau 26 hari dan pada waktu terjadi premenopause kejadian oligomenore meningkat. Panjangnya siklus menstruasi ini dipengaruhi oleh usia, berat badan, aktivitas fisik, tingkat stres, genetik dan gizi (Wiknjosastro, 2015).

Menurut penelitian Haniza, dkk tentang Hubungan Tingkat Stress Dengan Siklus Menstruasi Pada Wanita Usia 40-50 Tahun (Premenopause) Di Tlogosuryo Kelurahan Tlogomas Kecamatan Lowokwaru Malang, menyebutkan bahwa, hasil penelitian 
membuktikan lebih dari separuh 21 $(63,6 \%)$ responden memiliki tingkat stress sedang dan lebih dari separuh $18(54,5 \%)$ responden mengalami siklus menstruasi tidak teratur, sedangkan hasil uji korelasi pearson product moment didapatkan $\mathrm{p}$-value $=(0,002)<(0,050)$ sehingga dapat disimpulkan bahwa ada hubungan yang signifikan antara tingkat stress dengan siklus menstruasi pada wanita usia 40-50 tahun (premenopause).

Berdasarkan hasil penelitian dan pembahasan diatas maka menurut peneliti sebagian besar responden mengalami siklus menstruasi tidak normal, hal ini dikarenakan terdapat beberapa faktor Menurut Dieny (2014), terdapat beberapa faktor yang mempengaruhi gangguan siklus menstruasi, antara lain sebagai berikut: Genetik, Ras, Usia, Penyakit, Pertumbuhan Alat Reproduksi, Hormon, status gizi, aktifitas fisik dan Stress, dimana stress menyebabkan perubahan sistemik dalam tubuh, khususnya systempersarafan dalam hipotalamus melalui perubahan proklatin atau endogen opiate yang dapat memengaruhi elevasi kortisol basal dan menurunkan hormone lutein $(L H)$ yang menyebabkan amenorrhea.

\section{Hubungan Tingkat Stres Dengan Siklus Menstruasi Pada Wanita Premenopouse}

Berdasarkan hasil uji

statistik, didapatkan p-value 0,000 atau $p$-value < nilai a $(0,05)$ yang artinya terdapat hubungan tingkat stres dengan siklus menstruasi pada wanita premenopouse $\mathrm{Di}$ Wilayah Kerja UPTD Puskesmas Kusumadadi Kecamatan Bekri Kabupaten Lampung Tengah Tahun 2020 dengan nilai OR 4,542 yang artinya responden yang mengalami stress akan berpeluang 4,542 kali lebih besar untuk mengalami siklus menstruasi yang tidak normal.

Tingkat stress yang bisa menyebabkan siklus menstruasi tidak teratur karena stress sebagai rangsangan sistem saraf diteruskan ke susunan saraf pusat yaitu limbic system melalui tranmisi saraf, selanjutnya melalui saraf autonom akan diteruskan ke kelenjarkelenjar hormonal (endokrin) hingga mengeluarkan secret (cairan) neurohormonal menuju hipofhisis melalui sistem prontal guna mengeluarkan gonadotropin dalam bentuk FSH (Folikell Stimulazing Hormone) dan LH (Leutenizing Hormon, produksi kedua) hormon tersebut adalah dipengaruhi oleh $\mathrm{RH}$ (Realizing Hormone) yang di salurkan dari hipotalamus ke hipofisis. Pengeluaran $\mathrm{RH}$ sangat dipengaruhi oleh mekanisme umpan balik estrogen terhadap hipotalamus sehingga selanjutnya mempengaruhi proses menstuasi (Prawiroharjho, 2012).

Menurut hasil penelitian dan teori diatas sejalan dengan Kevin C. Tombokan tentang Hubungan antara stres dan pola siklus menstruasi pada mahasiswa Kepaniteraan Klinik Madya (co-assistant) di RSUP Prof. Dr. R. D. Kandou Manado, menyebutkan bahwa jenis penelitian ialah observasional analitik dengan desain potong lintang. Terdapat 34 responden yang diperoleh dengan teknik purposive sampling. Derajat stres dinilai menggunakan kuesioner Depression, Anxiety, and Stress Scales 42 (DASS-42) termodifikasi dan pola siklus menstruasi dinilai dengan kuesioner yang menggunakan skala ordinal. Data penelitian dianalisis dengan uji Spearman Rank Correlation. Hasil uji korelasi antara stres dan pola siklus menstruasi mendapatkan $p=0,014$ dan $r=0,417$

Berdasarkana hasil penelitian dan pembahasan diatas, maka menurut peneliti sebagian besar 
responden mengalami stress dan mengalami siklus menstruasi yang tidak normal, hal ini dikarenakan beberapa gejala psikologis yang menonjol ketika menopause adalah mudah tersinggung, tertekan, gugup, kesepian, tidak sabar, tegang (tension), cemas, stres, dan depresi sehingga mempengaruhi gonadotropin dalam bentuk FSH (Folikell Stimulazing Hormone) dan LH (Leutenizing Hormon, produksi kedua) hormon tersebut adalah dipengaruhi oleh RH (Realizing Hormone) yang di salurkan dari hipotalamus ke hipofisis. Dalam hasil penelitian yang peneliti lakukan, diketahui bahwasanya ada beberapa faktor yang mempengaruhi gangguan menstruasi, diantaranya usia yang tidak produktif kurang dari 20 tahun dan lebih dari 35 tahun, faktor stress, faktor asupan nutrisi yang kurang dan faktor kurangnya kebersihan gentalia.

Namun dalam hasil penelitian, peneliti menemukan bahwa terdapat beberapa responden yang tidak mengalami stress, namun siklus menstruasinya tidak normal, hal ini dikarenakan respon tubuh yang sifatnya non spesifik terhadap tuntutan beban atasnya. Dalam perkembangan selanjutnya ternyata dampak stres ini tidak hanya mengenai gangguan fungsional hingga kelainan organ tubuh, tetapi juga berdampak pada bidang kejiwaan (psikologik/ psikiatrik) misalnya kecemasan atau depresi. Gangguan pada sistem endokrin (hormonal) pada mereka yang mengalami stres adalah kadar gula yang meninggi, dan bila hal ini berkepanjangan bisa mengakibatkan yang bersangkutan menderita penyakit kencing manis (diabetes millitus), gangguan hormonal lain misalnya pada wanita adalah gangguan menstruasi yang tidak teratur.
Menurut penelitian Hanafiah (2012), lama haid biasanya antara 35 hari, ada yang 1-2 hari diikuti darah sedikit - sedikit kemudian, dan ada yang sampai 7-8 hari. Pada setiap wanita biasanya lama haid itu tetap. Siklus menstruasi, jika dalam 3 bulan terakhir, 2 bulan siklus yang normal maka dikatakana siklus normal.

Berdasarkan hasil penelitian yang peneliti lakukan, diketahui ada beberapa faktor yang mempengaruhi siklus mentruasi tidak normal, yaitu pekerjaan yang terlalu berat untuk responden, sehingga mengalami ketidak nyamanan fisik, sehingga segala aktifitas yang dilakukan oleh responden.

\section{KESIMPULAN}

Berdasarkan hasil penelitian diatas, maka kesimpulan dalam penelitian ini adalah: Diketahui bahwa Di Wilayah Kerja UPTD Puskesmas Kusumadadi Kecamatan Bekri Kabupaten Lampung Tengah, sebagian besar responden mengalami stress yang berjumlah 157 responden (51,6\%). Diketahui bahwa Di Wilayah Kerja UPTD Puskesmas Kusumadadi Kecamatan Bekri Kabupaten Lampung Tengah, sebagian besar responden mengalami siklus menstruasi yang tidak normal berjumlah 158 responden (52,0\%). Berdasarkan hasil uji statistik, didapatkan $\mathrm{p}$ value 0,000 atau $p$-value < nilai $a$ $(0,05)$ yang artinya terdapat hubungan tingkat stres dengan siklus menstruasi pada wanita premenopouse Di Wilayah Kerja UPTD Puskesmas Kusumadadi Kecamatan Bekri Kabupaten Lampung Tengah Tahun 2020.

\section{Saran}

Bagi UPTD Puskesmas Kusumadadi, hasil penelitian ini diharapkan agar dapat digunakan sebagai masukan untuk Puskesmas agar dapat 
mengadakan seminar atau pelatihan kesehatan tentang hubungan tingkat stres dengan siklus menstruasi pada wanita premenopouse, sehingga semua wanita premenopouse dapat mengatasi masa siklus menstruasi yang dialaminya.

\section{DAFTAR PUSTAKA}

Azwar, S. (2013). Sikap manusia dan pengukurannya. Yogyakarta. Pusat Belajar Offset.

Adayani. (2012). Cara Mengukur Status Gizi.Yogyakarta. Medical Book.

Dalami. (2010). Psikologi Stres. Yogyakarta: Nuha Medika.

Dieny, S. (2014). Permasalahan Gizi Pada Remaja Putri. Yogyakarta. Graha Ilmu.

Fithra Dieny, S. Gz. (2014). Permasalahan Gizi Pada Remaja Putri. Yogyakarta. Graha Ilmu.

Haniza, H., Widiani, E., \& Perwiraningtyas, P. (2018). Hubungan Tingkat Stress Dengan Siklus Menstruasi Pada Wanita Usia 40-50 Tahun (Premenopause) Di Tlogosuryo Kelurahan Tlogomas Kecamatan Lowokwaru Malang. Nursing News: Jurnal Ilmiah Keperawatan, 3(1).

Tombokan, K. C., Pangemanan, D. H., \& Engka, J. N. (2017). Hubungan antara stres dan pola siklus menstruasi pada mahasiswa Kepaniteraan Klinik Madya (co-assistant) di RSUP Prof. Dr. RD Kandou Manado. eBiomedik, 5(1).

Khamzah. (2015). Tanya Jawab Seputar Menstruasi. Yogyakarta. Flash Books.
Mugiati, M. (2016). HUBUNGAN ANTARA STRES DENGAN PERUBAHAN POLA MENSTRUASI PADA MAHASISWI KEBIDANAN TANJUNGKARANG. Jurnal Kesehatan Metro Sai Wawai, 8(1), 13-18.

Mulastin. (2016). Hubungan Antara Stres Dengan Siklus Menstruasi Di Pakuan Ratu Kalimantan Barat.

Notoatmodjo. (2010). Promosi Kesehatan. Jakarta. Rineka Cipta

Notoatmojo. (2014). Metodologi Penelitian Kesehatan. Jakarta. Rineka Cipta.

Nursalam, N. (2016). Manajemen keperawatan: Aplikasi dalam praktek keperawatan profesional. Jakarta: Salemba Medika.

Proverawati, A. (2009). Menarche, Menstruasi Pertama Penuh Makna. Yogyakarta. Nuha Medika

Profil Puskesmas Kusumadadi, (2019). Profil Kesehatan. Dinkes: Kabupaten Lampung Tengah.

Prawirohardjo, S. (2012). Pelayanan kesehatan maternal dan neonatal. Jakarta: YBP-SP.

Rakhmawati, (2013). Konsep Menstruasi Pada Wanita. Jakarta. Rineka Cipta.

Rosiana, D., Muljanto, R. B., KJ, S., \& Basuki, S. W. (2016). Hubungan Tingkat Stres dengan Keteraturan Siklus Menstruasi Pada Remaja Kelas XII di SMK Batik 1 Surakarta (Doctoral dissertation, Universitas Muhammadiyah Surakarta). 